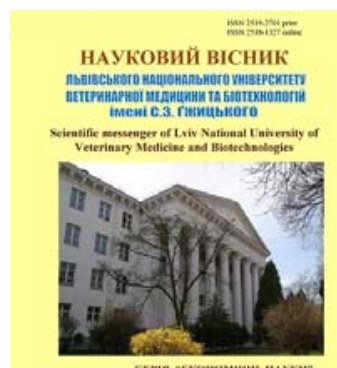

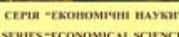 ветеринарної медицини та біотехнологій імені С.3. Гжицького. Серія: Економічні науки

\author{
of Veterinary Medicine and Biotechnologies. \\ Series: Economical Sciences
} \\ Scientific Messenger of Lviv National University \\ ISSN 2519-2701 print \\ https://nvlvet.com.ua/index.php/economy \\ doi: 10.32718/nvlvet-e9229
}

UDC: 665.238

\section{Cholesterol: for and against}

\author{
N.Yu. Koropetska ${ }^{1}$, Yu.I. Ostapyuk ${ }^{2}$ \\ ${ }^{1}$ Danylo Halytsky Lviv National Medical University, Lviv, Ukraine \\ ${ }^{2}$ Stepan Gzhytskyi National University of Veterinary Medicine and Biotechnologies, Lviv, Ukraine
}

Article info

Received 04.02.2019

Received in revised form 08.03 .2019

Accepted 11.03.2019

Danylo Halytsky Lviv

National Medical University,

Pekarska str., 69, Lviv,

79010, Ukraine.

Stepan Gzhytskyi National University of Veterinary Medicine and Biotechnologies Lviv,

Pekarska Str., 50, Lviv,

79010, Ukraine.

E-mail:hygiene@lvet.edu.ua
Koropetska, N.Yu., \& Ostapyuk, Yu.I. (2019). Cholesterol: for and against. Scientific Messenger of Lviv National University of Veterinary Medicine and Biotechnologies. Series: Economical Sciences, 21(92), 169-171. doi: 10.32718/nvlvet-e9229

The article deals with the value of cholesterol, as an essential component of each cell of the human body and its role in the synthesis process and as source material for male and female sex hormones, bile, acids, and vitamin D. Increased level of cholesterol in the body is a pathological phenomenon, leading to such diseases as atherosclerosis, myocardial infarction, liver and kidney disease, pancreatic disease, diabetes, obesity, and others. Lack of cholesterol, considering its multifaceted nature and the participation in the vital processes of the body leads to frequent depression, weakening of the immune system, increased fatigability, decreased libido and the development of other diseases. It has been demonstrated that $80 \%$ of cholesterol is produced by the human body; therefore it is not necessary to associate its excess or lack in the body with the quantity in food. Therefore, normally, our body regulates the level of cholesterol itself, keeping it within $5 \mathrm{mmol} / \mathrm{l}$ but in incorrect nutrition it is possible to increase its amount in the bloodstream. To reduce the cholesterol concentration in the body, it has been indicated which products should be restricted, and which ones to increase in the diet.

Key words: cholesterol, atherosclerosis, food products, body.

\section{Холестерин: за і проти}

\author{
Н.Ю. Коропецька ${ }^{1}$, Ю.І. Остап’юк² \\ ${ }^{1}$ Львівський національний медичний університет імені Данила Галицького, м. Львів, Украйна \\ ${ }^{2}$ Львівський національний університет ветеринарної медицини та біотехнологій імені С.3. Гљсицького, \\ м. Львів, Украӥна
}

У статті показано значення холестерину як невід'ємної складової кожної клітини організму людини та його роль у здійсненні процесу синтезу, а також вихідної речовини для чоловічих та жіночих статевих гормонів, жовчних кислот, вітаміну D. Підвищена кількість холестерину в організмі - явище патологічне, щьо призводить до таких захворювань, як атеросклероз, інфаркт міокарду, захворювань печінки і нирок, ураження підшлункової залози, иукрового діабету, ожиріння та ін. Нестача холестерину, враховуючи багатогранність його властивостей та участь у життєво важливих процесах в організмі, призводить до частих депресій, ослаблення імунітету, підвищеної втомлюваності, зниження лібідо та розвитку інших захворювань. Вказано, шьо 80\% холестерину виробляється організмом людини, тому не потрібно пов'язувати надлишок чи нестачу його в організмі з кількістю у продуктах харчування. Отюе, у нормі наш організм сам регулює рівень холестерину, утримуючи його в межах 5 ммоль/л, але при неправильному харчуванні можливе підвищення його кількості в крові. Для зниження концентрації холестерину в організмі вказано, які продукти слід обмежити, а які збільшити у раціоні харчування.

Ключові слова: холестерин, атеросклероз, продукти харчування, організм.

Холестерин являє собою жироподібну субстанцію (ліпоїд), яка міститься у кожній клітині нашого організму, а саме у клітинних мембранах. Там вона необ- хідна для розмежування клітин і відіграє головну роль посередника у клітинному обміні речовин. 3 цього випливає, що холестерин є життєво необхідним, оскі- 
льки без нього не може здійснюватись процес синтезу (Otto Wolff, 2002).

Холестерин належить до класу спиртів, тому його правильна хімічна назва має бути з суфіксом - ол, тобто холестерол.

У більшості джерел зарубіжної і вітчизняної літератури збереглась первинна назва - холестерин, хоча ще раз підкреслюємо, що правильна назва - "холестерол", але зважаючи на те, що частіше вживається термін холестерин.

Сьогодні достеменно вивчені широкий спектр властивостей і ролі холестерину в організмі людини. Так, він $є$ вихідною речовиною для багатьох дуже важливих, життєво необхідних субстанцій, які мають, насамперед, гормональний характер - для всіх чоловічих і жіночих статевих гормонів, а також для жовчних кислот і так званого вітаміну D. Сказаного цілком достатньо, щоб зрозуміти абсолютну життєву необхідність холестерину. I те, що останніми роками холестерин буквально проклинають, є неправильним.

Звичайно, є об'єктивним і правильним те, що підвищена кількість холестерину - явище патологічне і надмірне його відкладання веде до такого небезпечного захворювання, як атеросклероз. Але це стосується й інших речовин, наприклад, підвищена кількість цукру при захворюванні цукровим діабетом так само небезпечна, як підвищений вміст сечової кислоти при подагрі.

В історії з холестерином причину цього знайшли дуже швидко: вирішили, що вся справа в харчуванні, i як наслідок - холестеринвмісні продукти харчування десятиріччями вважалися винуватцями небезпечних відкладень в організмі й відповідно таких захворювань як інфаркт міокарда, атеросклероз, захворювання печінки і нирок, ураження підшлункової залози, а також цукровий діабет, порушення функції щитоподібної залози, ожиріння та ін.

При цьому зовсім не брали до уваги таку дуже важливу обставину, що організм сам виробляє холестерин. Незаперечним фактом є те, що $80 \%$ холестерину виробляється організмом людини. 3 цього - логічний висновок, що здоровий організм сам регулює потребу холестерину і його надлишок чи недостачу не потрібно пов'язувати 3 його кількістю у продуктах харчування.

Водночас не так давно 3'ясувалося, що причиною названих захворювань $\epsilon$ не сам холестерин, а скоріше продукти його старіння, які виникають передовсім через неправильне зберігання під дією світла і кисню (повітря). Особливо небезпечними $є$ продукти окиснення холестерину, яких вже встановлено понад вісімдесят. Деякі з них навіть у дуже малих кількостях здатні швидко (вже через добу) викликати серйозні зміни у кровоносних судинах, тоді як чистий холестерин використовується безпосередньо у процесі обміну речовин. Тому цілком правдоподібно, що відкладений у судинах холестерин дійсно потрапляє в організм 3 їжі, але вже не як власне холестерин, а у вигляді надзвичайно небезпечних продуктів його старіння.

Таким чином, свіже яйце, свіже молоко, свіже вершкове масло не становлять ніякої “холестеринової" небезпеки на противагу яєчному порошку (у конди- терських виробах довготривалого зберігання), сухому молоку чи м'ясу, які неправильно зберігалися (Otto Wolff, 2002).

Отож вирішальний момент: “за” чи “проти” - відомо що ні масаї (жителі східної Африки), які харчуються виключно молоком і молочними продуктами, ні ескімоси, які споживають тільки м'ясо і тваринний жир, не мають підвищеної кількості холестерину і не страждають від атеросклерозу чи подібних захворювань. Однак варто наголосити, що ці народи їдять свої харчові продукти виключно у свіжому вигляді (Huseman/Wolff, 1993; Otto Wolff, 2002).

Якщо холестерин не використовується, то він випадає в осад, що проявляється у вигляді атеросклерозу - типовій хворобі старіння. У випадку, коли холестерин засвоюється організмом, тобто змінюється, піддаючись легкому розкладанню, утворюються вже названі необхідні продукти: жовчні кислоти, гормони, вітамін D, продукти секреції наднирників - активні речовини, кількість яких 3 віком зменшується. Це зменшення сигналізує про таке явище, як недостатнє розщеплення холестерину.

Отже, незважаючи на велику кількість досліджень властивостей холестерину, навіть атеросклероз досі залишається не вирішеною до кінця проблемою, а пошук надійного методу його запобігання та лікування продовжується.

Та як би ми не трактували знання про холестерин - безперечно він необхідний нашому організму. $€$ повідомлення, що на заході визначення рівня холестерину в крові стало буденною процедурою - люди стежать за цим показником, незважаючи на те, що саме слово “холестерин” у громадській свідомості набуло явно негативного відтінку.

Як уже згадувалось, у нормі наш організм сам регулює рівень холестерину, утримуючи його в межах 5 ммоль/л. Підвищення тільки на дві одиниці, тобто до 7 ммоль/л, є загрозливим, оскільки підвищує ризик смерті від ішемічної хвороби серця удвічі.

При високому рівні холестерину в крові лікарі рекомендують зменшити споживання жирів, але при цьому варто розрізняти насичені жири (наприклад вершкове масло), які підвищують рівень холестерину і ненасичені (наприклад рослинна олія), які не завдають шкоди і потрібні організму.

Необхідно пам'ятати, що холестерин міститься лише у продуктах тваринного походження.

Крім цього, побутує думка, що найкращим рослинним засобом, який виводить з організму холестерин, є часник. Може, тому наші предки призвичаїлись їси сало з часником. Ще один природній засіб, який має антиоксидантні властивості та здатний виводити холестерин - зелений чай.

А ця інформація потішить людей, які шукають виправдання своїй пристрасті: алкоголь може виводити холестерин з організму. Однак ці “ліки” вимагають дуже виваженого дозування, тому що така боротьба 3 холестерином може завдати тій же серцево-судинній системі значно більшої шкоди, ніж сам холестерин. Та й прикро буде, остерігаючись інсульту чи склерозу, помирати від цирозу печінки. 
Зниження холестерину нижче за норму теж шкідливе, адже нестача його, враховуючи багатогранність його властивостей та участь у життєво важливих процесах в організмі, призводить до частих депресій, ослаблення імунітету, підвищеної втомлюваності, зниження лібідо та розвитку інших захворювань. У крові він транспортується в чистому вигляді, тому його нестача або надлишок часто призводять до захворювань серцево-судинної системи.

Холестерин необхідний також для роботи мозку, тому що постачає його необхідними антиоксидантами та у достатній кількості допомагає організму засвоювати жири.

Причини підвищеної кількості холестерину в жінок і чоловіків можуть бути різними. Найчастіше нездоровий спосіб життя, надмірне споживання жирної їі та гіподинамія (мінімум фізичних навантажень). Ситуація може ускладнюватися шкідливими звичками: курінням та вживанням алкоголю.

Ризик гіперхолестеринемії збільшується за наявності стресів, спадкової схильності і з віком. У середньому віці захворювання частіше виявляється у чоловіків, але з настанням у жінок клімаксу перевага переходить до них.

Оскільки найчастіше причиною підвищення холестерину в крові є неправильне харчування, то цілком логічно виправдано, що грамотно складений раціон допомагає досягти зниження рівня цього показника.
Враховуючи той факт, що $80 \%$ холестерину виробляється в організмі печінкою, а $20 \%$ надходить з3овні, тобто з їжею, можна при підвищеній концентрації його в крові зменшити споживання продуктів, багатих на холестерин.

Для зниження холестерину в крові варто обмежити споживання, насамперед, тих продуктів, які містять цей ліпоїд у великій кількості, а далі збільшити використання овочів, ягід, фруктів, злаків, бобових, часнику, зеленого чаю, нежирних або знежирених молочних продуктів, а також тих, які впливають на функціонування печінки. Це такі, як горіхи, особливо фісташки, баклажани, авокадо, морква, журавлина, оливкова олія, помідори, вівсянка, цитрусові. Варто зауважити, що реалізація даних порад не одраз й не завжди дає бажаний результат, але врахування цих рекомендацій у кожному разі позитивно позначиться на вашому здоров

\section{References}

Vol'f Otto (2002). Chto my edim? Prakticheskij vzgljad na pitanie. M.: Prosvetitel'skij fond "Jevidentis", OOO "Dobraja kniga" (in Russian).

Husemann / Wolff (1993). Das Bild des Menschen als Grundlage der Heilkunst, Bd. 2 und 3, Stuttgart. 